\title{
Tõlke vältimatusest
}

\section{Toomas Kiho}

doi:10.7592/PS/28-7kiho

Janika Kronberg helistas mulle eelmisel nädalal just siis, kui olin lugemas Postimeest. Oleksin ma teadnud, et ta oma telefonaadiga tuleb, "oleksin kohe kodust ära läinud", kui fraseerida Oskar Lutsu Tõnissoni. "Tule ja pea Kreutzwaldi päevade avakõne, kõik teised on ära öelnud, kokkulepetest taganenud," ja nii viimasel hetkel ei söanda ta kedagi teist paluda. Härra direktori jutt sarnanes ettepanekuga, mida ei saa tagasi lükata. Ettepanek oli ka täitsa ootamatu. Tunnistan, eriti siinse auditooriumi ees piinlikkusega, et Kreutzwaldi päevad pole minu aastakalendris kunagi tähtsale kohal paigutunud - kuigi tihtigi on Kreutzwaldi päevadel huvitavaid ettekandeid peetud, siin on mõnigi kord olnud seda kultuurilist kõrgtaset ja tulevärki, mida iga kirjandushuviline võiks nautida. Ja seetõttu on kahju, et need kirjaduse tipp-päevad on enamasti jäänud jõuluaegsete askelduste alla või mattunud aastalópu sahmimistesse. Vanal sovetiajal pealegi torgati need päevad teinekord otse jõulude südamesse.

Niisiis eksitati mind lehelugemisel. Mida siis sealt Postimehest olin teada saanud? Lugesin üht hariduse tuleviku arutelu, mis oli Goethe Instituudi rahastusel aset leidnud. Postimees vahendas Mati Heidmetsa sõnu: "Tuleviku ülikoolis on ingliskeelset juttu rohkem. Vaatamata meie ponnistustele eestikeelse haridus- ja teadusruumi osas..." Meie ponnistused?! See on üks halvakõlaline 
sõna, mis väljendab ülemäärast, liigset pingutust... Veelgi selgemalt ja ühemõttelisemalt väljendab sedasama Ott Pärna, Eesti Arengufondi juht. Ja kellelt siis veel kui arengufondlaselt võiks Eesti tuleviku kõige selgemat ettenägemist oodata? Pärna ütleb: "Loodan, et selleks ajaks on kadunud ära veelahe Eesti ja maailma vahel - Eesti kõrgharidus on rahvusvahelistunud, valdav osa õppetööst käib inglise keeles, seda isegi bakalaureuse tasandil. Usun, et alates aastast 2015 on meil teemaks inglise keele tõstmine Eestis teise riigikeele staatusesse ning 2020. aastal see saabki teoks. Inglise keel teise riigikeelena tagab avatuma keskkonna rahvusvahelistele õppejõududele ja nende peredele. /---/ Võimalus siin inglise keeles asju ajada on selle [et Eesti on palju rahvusvahelisem kui praegu - T.K.] vaieldamatu eeltingimus." Ning veel üks üllatav passus Pärnalt: "Inglise keel teise riigikeelena aitab teisalt kaasa vene keelt emakeelena rääkivate noorte ühendamisele Eesti majandusse ja teadusellu"!

Ja seda kõike rahastatakse viigilehe tagant, millele on kirjutatud suure valgustaja Johann Wolfgang Goethe nimi! Kuidas hinnata neid arengufondi fantasme? Kui need pole riigivaenulikud, siis Eesti-vaenulikud on need kindlasti. Vähemalt sellise Eesti vaenulikud, mille nimel on vaeva näinud need sajad ja tuhanded kultuurikandjad, kelle töö viljad on koondatud kas või siia templisse, kirjandusmuuseumisse ja tema hoidlatesse.

Üks ilmekas katke või resümee veel Arengufondi juhatajalt: "Eestist on saanud mitmetes valdkondades teaduselu network'i keskus." - Sellest kumab veendumus saada suureks arvult - seisukoht, mida on Eesti kultuurikonteksis küll alati võimatuks sündmuseks loetud. Vastupidi väitjaid on siinmail leebelt öeldes ullikesteks peetud.

Ja ega Ott Pärna ei ole ju üksi. Lihtsalt tema kui ex officio Eesti arengu suunaja jutupunktidel on suurem kaal kui mõnel niisama ütlejal. Toon veel mõned väljaguugeldunud näited. 
Suhtekorraldaja Raul Kalev kirjutab Delfis 17. mail 2011': "Inglise keele teiseks ametlikuks riigikeeleks nimetamine oleks ennekõike märgilise tähendusega ja minu hinnagul suur samm kultuuri kaitsvast isoleeritusest välja. Ja ka signaal Euroopale, mis ärataks meie vastu ehk suuremagi huvi kui eurotsooniga ühinemine seda suutis.” Kultuuri kaitsva isoleerkihi kõrvalejätmine ei tähendaks ju miskit muud kui omaenda kultuuri eitust, kultuuri mahasalgamist, kultuuritust või (veel heal juhul) ümberkultuuristumist, s.o mõne teise kultuuri isoleerkihi omandamist.

Statistikaameti peaanalüütiku Mihkel Servinski hinnangul on praeguse suuna jätkudes selge, et Eesti võib mingist hetkest elu-olu vabalt kulgeda ka inglise keeles. "Eesti arvamusliidritel on tekkinud mõte ingliskeelse elu-olu loomise vajadusest ja see on avalikult ka välja öeldud. Pragmaatiliselt võttes on mõttel ka jumet võib olla üsna kindel, et ingliskeelse elu-olu keskkonna olemasolu tugevdaks Eesti positsiooni majanduselu rahvusvahelises konkurentsivõitluses," kirjutas Servinski 1. augustil 2011 statistikablogis ${ }^{2}$.

Need on viimase aja näited, kuid ka juba tosina aasta eest kirjutas nt Äripäev (13.9.1999): "Eestisse enim välisraha vahendanud Joakim Helenius avaldas sisuka mõtte, et Eesti peaks kehtestama inglise keele ametlikuks riigikeeleks. Eeskuju on võtta kasvõi Singapurist, sellest äärmiselt kiire majandusarenguga riigist. Äripäev toetab inglise keele kehtestamist riigikeeleks - Eesti muutmist kakskeelseks (eesti ja inglise keel) riigiks. Idee plussid on selgelt näha. Kakskeelsena kiireneb oluliselt Eesti integreeritus Euroopa ja terve muu maailmaga. Välisinvestoritel on palju lihtsam tulla riiki, kus asjad saab korda aetud - jah, seda väljendit pole tarvis karta - rahvastevahelise suhtlemise, s.o inglise keeles. Märkimisväärselt lihtsustub panganduslik, teaduslik, normatiivne ja muu praktika, mis tegelikult käib juba praegu inglise keeles. Lihtsalt mindaks üle de facto'lt de jure'le."

1 http://www.delfi.ee/news/paevauudised/arvamus/raul-kalev-inglise-keelriigikeeleks.d?id=46065875

2 http://statistikaamet.wordpress.com/2011/01/08/rahvaloendus-ja-inglisekeele-oskus/ 
Rahvastevahelise suhtlemise keel, hoolimata Äripäevas väljendatud lootusest, kõlab ikkagi ehtsa reliktväljendina Brežnevi ajast. Ja too oli ju mäletatavasti aeg, millest me kõik ä r a tahtsime, ja kõik selle heaks ka tegime.

Eesti riigi ülesehitusloogikas on alati - nii enne tegelikku riigiloomet või -taastamist kui ka tegeliku konstitueerimise käigus - lähtutud klassikalisest rahvuslusest, millel oli Eesti riigi taastamisel juhtiv roll. Seda vaimu kannab rahvahääletusel ülekaalukalt heaks kiidetud 1992. aasta põhiseadus, mille preambulas on eesmärgina sõnastatud ülesanne tagada eesti rahvuse, keele ja kultuuri säilimine läbi aegade. See on ilmselt viimase aasta jooksul kõige enam meenutatud kirjakoht põhiseadusest. Vähem mäletatakse, et põhiseaduse paragrahv 6 ütleb otsesõnu: "Eesti riigikeel on eesti keel", millega on üheselt välistatud see, et Eestis võiks olla riigikeeleks - kas eesti keele kõrval või eesti keele asemel - mõni muu keel, olgu siis vene või inglise vm. See on olnud üks suur võit, mille eesti rahvas on saavutanud viimaste aastakümnete jooksul - üheks võitluse lähtepunktiks võiks pidada ka 1980. aasta murelikku 40 kirja.

Kuidas on eelöelduga seotud minu teema, tõlke vältimatus? Kõige otsesemalt. Nimelt on päris selge, et inglise keele teise riigikeele staatusesse tõstmine tähendaks Tõlkimatust. Seisundit, kust oleks kadunud tõlke tarvidus, vajadus tõlkimise järele. Sest kui inglise keel on riigikeel, siis on selles keeles kõikvõimalik riiklusele, aga ka kultuurile jm vajaminev teave olemas - kätte- ja arusaadav kõikidele. Kõige eesti keelde ümber panemise järele kaoks vajadus. Aga eestlased tõlkimata ei saa. Eestlane poleks kultuurrahvas ilma tõlkimiseta. Kui nüüd tõlkimise vajadus kaoks, siis vallutaks Tõlkimatuse staadium Eesti kultuuriruumi ning see tähendaks minu hinnangul kaht: kõigepealt, nagu öeldud, vajaduse kadumist tõlke järgi. Kui kõik on juba inglise keeles, siis on tekkinud Paabeli-eelne olukord ning tõlkimine kaob minevikuigandina ajalukku. Kaob 
tõlkekultuur. Kaob vajadus eesti keeles mõtelda ja kirjutada, kaob võõrtekstide kodustamise - mida tõlkimine ju on - tarve. Pikapeale vajub surnud teaduse osasse ka võrdlev filoloogia, kõik tõlketeooriad, meie keel astuks surnud keelte armeesse. Muidugi ei juhtuks see vist veel aastaks 2020, aga varsti ikka. Pääsu ei oleks. Aga eesti tõlkekultuuri kadumine oleks veel väikene häda. Palju suurem mure on teine järeldus. Nimelt tähendaks see kultuuri lõppu üldse. Selline kultuur, kes ei tõlgi, lõpeb. See kultuur vaikiks. Muutuks tühjaks, eimiskiks. Seepärast on kohane hüüatada: arengufond viib meid hukatuse teele!

Kui mu eelnev jutt üldse midagi tähendab, siis ikka just vastupidist: tõlge on vajalik. Tõlge on vältimatu, eriti meile siin, eestlastele. Tõlke vältimatusest kõnelda siin seesuguse auväärt kuulajaskonna ees on ettevaatamatu. Kõik mõistame ju kohe, et iga maailmakultuuri tekst, mis eesti keelde siseneb ehk siis läbib kultuurilise isoleerkihi või kultuurilise atmosfääri, paigutub siin, meie kultuuris, mingile ettemääratud kohale. (See ettemääratuse määr on omaette teema, millel siin peatuda ei tahaks - märgin lihtsalt, et vahel osutub mõni tõlge tähenduslikumaks kui mõni teine, aga milline just, pole alati ette selge. In memoriam Andres Ehini puhul olgu siin ettemääratult kõrgekohalisena mainitud "Tuhandet ja üht ööd". Kreutzwaldi puhul muidugi Kalevipoega, nagu iga tema tõlget ja ükskõik kumba pidi.) Niisiis: tõlgitud tekst saab meie omaks, ja vaheparadoksina: meilt väljatõlgitud tekst jääb meie omaks, mõelgem või vastsele Kalevipoja ingliskeelsele tõlkele. Neil päevil oli Eesti Rahvusraamatukogus väljas näitus eesti tõlkekirjandusest. Eesti kirjanduse teabekeskuse tegevjuhi Ilvi Liive sõnul näidatakse viimase kümne aasta jooksul eesti keelest tõlgitud raamatuid, kokku on näitusel väljas 267 raamatut 27 keeles. Mõlemal juhul, nii meile sissetõlgitud tekstide puhul kui ka väljatõlgitute puhul, on kontekst, raam oluline. Pakend, millesse tekst paigutub. Õigem oleks ütelda: kultuurikontekst, millesse üks või teine nähtus satub. 
Tõlkimine, igakülgse tõlkekultuuri olemasolu on väikesearvulise kultuuri jaoks eriti oluline - selleks et olla täisväärtuslik, koknurentsivõimeline, peame meie eriti palju tõlkima. "Tõlkida, tõlkida nagu hullud," see on "ainus võimalus", kui osundada siin korraga nii Maurust kui Gabrieli, kes ju mõlemad mingis mõttes on olnud eesti kultuuri tõlkijad. Tõlkimine on meie jaoks vältimatu, ta on nagu õhk. Õhku tarbivad nii valaskalad ja suurkultuurid kui uruhiired ja pisikultuurid. See annab meie kultuuriorganismile vajaliku annuse hapnikku, eluõhku, see tähendab uusi mõisteid, mõtestamisi ja ümbermõtestamisi, diskursusi ja paradigmasid. See annab meie lastele võimaluse omandada arusaamine maailmast eesti keele vahendusel. See tähendab olukorda, kus terve ilm alates köögist kuni kosmoseni on seletetav emakeeles. See on ideaalpilt, mida võib vist pidada kogu eesti kultuurilise eksistentsi seniseks keskseks kreedoks ja mõtteks. Selle pildi kooshoidmise ja kokkuseadmise eest oleme kõik vastutavad. Eriti aga tõlkijad. Tõlge on vältimatu!

Ja egas tõlkijad pole ainult luulevahendajad või ilukirjanduse tõlkijad. Tegelikult oleme tõlkijateks me ise, igaüks. Meie enda vastutuses on oma keelt ja väljendusi hoida selged ja klaarid - nagu öeldud: köögist kosmoseni. Köök tähendab siis seda, et me ei risustaks oma igapäevakeelt tarbetute võõrväljenditega, vaid kodustaksime need. Ka kosmose poolel on lugu sama: vältimatu on kinni pidada näiteks nõudest, et väitekirjade kokkuvõtted ilmuksid eesti keeles, et terve mõte oleks eesti keeles olemas, arendatav. Ja ei iialgi valmis.

Ja lõpuks on tõlketekstide hulgas nagu looduslikus ökosüsteemis igal osalisel oma roll: kes on ürask ja kes lagundaja, kes kasvataja, kust tekivad sümbiootilised kontaktid ja kokkupuuted, kus on kõrgelt arenenud vormid ja kus kaunimatest kaunimad õied. Nii on igaühel õigus kohale eesti kultuuripäikese all. Nii Barbara Cartlandil kui Paulo Coelhol, nii Viplalal kui Harry Potteril. 
Kolme olulist mõttelõnga tahaksin ses seoses veel teiega jagada.

\section{1.}

Tõlkevajadus $v s$ emakeelne mõtlemine. Olen üsna kindel, et masinad õpivad üsna varsti tõlkima. Ja see ei tähenda inimeste laiadele massidele mitte mõtlemist, kirjutamist või õppimist inglise keeles, vaid just igaühe emakeeles. Masinad teevad vaid musta töö. See murrang saabub varem või hiljem, nii nagu tänapäeval pesevad pesu masinad ja ka rõivaid õmmeldakse masinatega, niisamuti on varsti võimalik näiteks telefoniliides kuuldetoru ja kõrva vahel, mis tagab selle, et torusse kõneldud teiskeelne jutt moondatakse enne minu kõrva jõudmist eestikeelseks. Näiteid võiks veelgi tuua.

\section{2.}

Tänavu tõi rahvusvaheline suurajakiri National Geographic välja eestikeelse ajakirja. Nemad ei põlga miljonilist kultuuriturgu väikeseks. Eesti keelde pannakse järjekindlalt kogu Euroopa Liidu juriidika, europarlamendi sõnavõtud ja muu sarnane. Ka seal pole eesti keel liiga väeti ega nõder. Arvutisõnavara on viimasel aastakümnel laialdaselt eestindatud, eesti keeles suhtlevad meiega nii Google, IBM kui Apple, seda hoolimata mõnegi hooplemisest, et "kentsakat eestikeelset sõnavara ses asjanduses mina küll omaks ei võta". Ning samal ajal anname meie vabatahtlikult kultuuripositsioone eesti keele käest ära!? See meenutab déjà vu olukorda, kus eesti kadakad aktiivselt saksat pursivad, oma lapsi saksa koolidesse panevad, samal ajal kui edumeelsemad sakslased - parunid, pastorid või literaadid - hoopis eesti keelt ja grammatikat uurivad, eesti keeles värsse kirjutavad ning üldse maarahva harimise peale mõtlevad. 


\section{3.}

Kas olete tähele pannud, et turuliberaalne majandus ei kasuta inglise keelt seal, kus vene keel suuremat sissetulekut tõotab? Ja vastupidi: seal, kus arvatakse, et inglise keel on moekam, seda ka kasutatakse. Näiteks igasugused kommunaalteadaanded prügiveo, olmeelektroonika allahindluste ja kaltsukate kohta, maximate ja onoffide reklaamid, need, mis elanikele postkastidesse jaotatakse, on eesti ja venekeelses paralleeltõlkes. Teine teisel lehepöördel, inglise keel seal puudub. Täna hommikul tõi post sellise lehe: "Ostame kulda ja hõbedat! / Покупаем золото и серебро!”, mitte mingit "We buy gold and silver!"

Seevastu firmanimedes, samuti tootenimetustes eelistatakse inglise keelt, pahatihti isegi eestikeelse vasteta (või on see imepisikirjas, mida keegi lugeda ei näe). Paar näidet tänaselt poeletilt. Ostsin toidupoest ühe kollase purgi, sellel on tekst "Dynami:t. Energy drink. With natural caffeine. 1 pint $=0,568$ 1. 13,6\% for free compared to 0,5 1 bottle - recommended retail sales standard shelf price", ja kaanepaberil seisab "Win a trip to New York". Mitte ühtki eestikeelset sõna, et aru saada, mis peitub purgi sees. Ainus vihje Eestile on veebiaadressi laiend samas kaanel: www.dynamit. ee. (Muide, tegu ongi kodumaise toodanguga, kuid selle teadasaamiseks peab purki luubiga uurima, et matsikeelset teksti näha.)

Või mu teine ost, šokolaad. Mida loeme selle paberilt? Seal on tekst, mis on keeleliselt eriti õel lastele meelepärase toote puhul. Paberit vaadates võib jah arvata, et küllap siin sees, pakendi kuju järgi otsustades, ikkagi šokolaad on, kuid paberile on kirjutatud vaid sellised sõnad: "Kalev Désirée, Caffè latte flavoured milk chocolate with a feeling... and filling." Miks peaksid meie lapsed selle toote eestikeelset vastet teadma või seda tõlkida oskama? 
Tõlke vältimatust tuleb rõhutada kõikjal, aga kindla peale just siin, kirjandusmuuseumis. Kui kõik muu ka langeb, siis... See asutus on nagu meie viimane kants - nagu tsiviilkaitsevarjend, kus üle elada karmid rünnakud (kui tuua paralleel nõukogude ajast), või nagu muistne pelgupaik soosaarel (kuhu sõjarünnakute eest varjuda ning kus säilitada ja säilida). Siia maalinna on aastakümnete jooksul koondatud meie tagavarad, meie kultuurilise kestmise tagatised. Kuni väljas annavad lahingut (keele)vallutajad ja (keele)barbarid ning meie positsioonid nõrgenevad, koguneme seesugustesse kantsidesse nagu kirjandusmuuseum ja peame vastu.

Kirjandusmuuseumi roll rahvusarhiivina, kirjanduse varaaidana, kuhu salvestub järjepidevalt meie kultuurikiht, on ülehindamatu. Kust mujalt seda protsessi veel parem jälgida oleks kui siit kirjandushoidla varasalve servalt. Siin olles ja töötades võib end tunda eelajaloolise molluskina, kelle silme all kirjandus paeseks kultuuripinnaseks ladestub. Aastakäik aastakäigu järel tulevad siia ajakirjad, ajalehed koos oma ajalike murede ja kitsaskohatedega. Aga tulevad ka kopsakad kihid rahvuskultuuri - mõelgem nende all siis teaduslikumaid tekste, kuid eeskätt vist ikka ilukirjandust, seda pärlite pärli, kirjanduse kaunimat kihistust. Ja siin seisab muidugi erilisel kohal Kreutzwald oma Kalevipojaga, nagu on kohane meenutada tänasel päeval, mil siinsamas esitletakse Triinu Kartuse eeposetõlget. 